\title{
Value contributions of the venture capitalist in Mexico: building an exit for the investment
}

\author{
Enrique Wiencke ${ }^{1}$
}

\begin{abstract}
Venture capitalists provide money and non-monetary contributions to high-growth ventures to help them become great companies. Although it is known that these contributions have an impact on the growth of the firm, little is known in Mexico of their nature, how they get into the venture, and how they contribute to the development of the company. The present article reports a proposed substantive theory that explains how the venture capitalist work hand in hand with the entrepreneur to grow the company. This substantive theory emerged from data collected through interviews to nine venture capitalists and nine entrepreneurs, and analyzed as proposed by the grounded theory methodology. The resulting substantive theory acknowledges that contributions of venture capitalists, often called value-added, are relative to building an exit for the investment.
\end{abstract}

Keywords: venture capital; venture capitalist; value-added; high-growth venture; high-growth entrepreneur; innovation; high-tech; venture financing; grounded theory; Mexico.

Submitted: July $7^{\text {th }} 2017$ / Approved: September $25^{\text {th }} 2017$

\section{Introduction}

The venture capital industry was born in the United States of America, U.S.A., in 1946 when the firm American Research and Development was created to invest in technology-based young firms, however it was not until the $70 \mathrm{~s}-80$ s, mainly due to regulatory changes, when the industry attracted more money and venture capitalists (Gompers \& Lerner, 2006). Today, venture capital is recognized as the main source of innovation and new jobs, and the growth engine of an economy (Lerner, 2009). Venture capital is new in Mexico and is in its early-stage of development. From 2010 to 2016, deals closed in Mexico were 522 vs. 59,005 in the U.S.A., and exits in Mexico were 21 vs. 5,981 in the U.S.A. (NVCA, 2017; "Overview of the venture capital industry in Mexico - October 2016," 2017). Due to the attractiveness of this industry worldwide, the Mexican government initiated efforts to detonate the growth of venture capital at the beginning of this millennium. For example, the government created the venture capital fund Fondo Emprendedores CONACYT-NAFIN to invest in ventures based on scientific and technologic breakthroughs in 2004, the venture capital fund of funds Mexico Ventures I to increase the number of independent venture capitalists in the country in 2010, and the seed capital fund Fondo de Coinversión de Capital Semilla to increase the number of viable business opportunities for the venture capital industry in 2013 (Ramírez, 2015). Today, despite these efforts to invigorate the industry that resulted in the creation of 14 venture capital funds ("Estadísticas," 2017), venture capital is referred to as "capital emprendedor" in Mexico, venture capital financing is still barely known in Mexico.

Venture capital is a special kind of financing. The venture capitalist uses money from investors to capitalize very risky business opportunities, most of them with innovative products and services which usefulness has not yet being accepted by the market (Hellmann \& Puri, 2000). The venture capitalist knows how to minimize risks and has special knowledge and capabilities to grow ventures (De Clercq \& Manigart, 2007). On the other hand, the high-growth entrepreneur creates ventures that, unlike traditional entrepreneurial endeavors, transform innovative ideas into high-value-added products for very large markets (Hellmann \& Puri, 2000). Thus, when looking for financing, the high-growth entrepreneur chooses a venture capitalist with the money needed to market his product, and with knowledge and abilities to help him grow his venture (Knockaert, Lockett, Clarysse, \& Wright, 2006). The venture capitalist and the high-growth entrepreneur become partners and work together to grow the venture exponentially, in a working relationship that will last for several years.

The venture capitalist - entrepreneur relationship begins when the entrepreneur pitches his business opportunity to the venture capitalist, and often prevails until the venture capitalist withdraws his investment from the company. The venture capitalist is not just a provider of financial resources to the venture, he becomes an owner of a stake in the venture. The initial and dominant approach to study the venture capitalist - entrepreneur relationship reported in the literature was the agency problem (Arthurs \& Busenitz, 2003). The belief was that the entrepreneur behave opportunistically due to misaligned objectives and contrasting risk preferences with respect to the venture capitalist. Contrary to opportunistic behavior and self-interest, later the characterization of the relationship was one of trust and collaboration (Leece, Berry, Miao, \& Sweeting, 2012). From this perspective, the entrepreneur seeks to improve the performance of the venture because: (a) his interests are aligned with those of the venture capitalist and the organization; (b) he perceives justice in dealing with the venture capitalist and consequently does his best effort; and (c) he has economic motives to cooperate and promote a collaborative

(1) Department of Economics and Business, Universidad Anáhuac México, Av. Universidad Anáhuac No. 46, Huixquilucan, México. E-mail: enrique.wiencke@anahuac.mx 
relationship with the venture capitalist. The new approach suggests that a good venture capitalist - entrepreneur relationship is necessary for the development of the venture.

Despite the fact that activities carried out by the venture capitalist in the U.S.A. are reported in an abundant literature, little is known about the value contributions of venture capitalists. How do they add value to their companies? In particular, what are the venture capitalists' resources transferred to the company? what are the mechanisms used by venture capitalists to add value? and what are the factors that impact on those mechanisms that finally determine the value added to the company? Knowing about how value added is created between the venture capitalist and the high-growth entrepreneur could contribute to open the black-box of the venture capitalist's involvement, and reduce the number of venture capital-backed firms that fail. Gage (2012) places the number of venture capital-backed firms that fail at $75 \%$. Therefore, the objective of this article is to explain the value contributions of the venture capitalist to the venture in Mexico. Following this introduction, the article describes the activities carried out by the venture capitalist reported in the literature, describes the qualitative approach used to analyzed data, introduces the study's participants, presents the substantive theory that emerged from the information provided by the participants, and suggests implications of the study.

\section{Literature Review}

The literature on venture capital seeks to understand two main phenomena related to the venture capitalist journey of making a return on his investment: how venture capitalists choose investment opportunities, and how they contribute to grow the venture. In this regard, the venture capitalist not only knows how to choose successful business opportunities but he also knows how to build them (Baum \& Silverman, 2004). The following literature review seeks to understand the contributions made by the venture capitalists to grow the venture. Based on the framework proposed by Sapienza \& Villanueva (2007), the review focused on the independent venture capitalist, took into account the perspectives from both the venture capitalist and the entrepreneur, and contemplated the activities carried out by the venture capitalist once the cash arrived into the company. Overall, contributions of the venture capitalist are intended to balance the inexperience of the entrepreneur to manage growth, to satisfy the entrepreneur's advisory needs, and to introduce corporate governance into the venture (De Clercq \& Manigart, 2007; Large \& Muegge, 2008). In the remaining of this section, a differentiation is made between direct and indirect contributions of the venture capitalist. In addition, there is still and ongoing debate on whether the venture capitalist adds value to the venture that is addressed at the end of this section.

\section{Direct Contributions}

The venture capitalist contributes directly to the venture by informally participating in meetings with the entrepreneur and through telephone calls and e-mails, to name only a few (Maunula, 2006). The frequency of these venture capitalist - entrepreneur's interactions depends on the characteristics of the venture capitalist, the entrepreneur and the venture. For example, the greater goal congruence between the venture capitalist and the entrepreneur, the more entrepreneur's new venture experience, the greater the geographic distance between the venture and the venture capitalist, the higher the venture stage of development, and the less degree of technical innovation the venture is pursuing, the smaller the frequency of interactions (Sapienza \& Gupta, 1994). The formal participation of the venture capitalist in the venture is through the board of directors, often with a controlling position of the company (De Clercq \& Manigart, 2007). From the board, the venture capitalist acts like a sounding board, monitors the financial and operational performance of the company, and makes sure that the management fulfills its obligations (Gabrielsson \& Huse, 2002).

Large \& Muegge (2008) group the most common direct activities carried out by the venture capitalist into matters related to recruiting, mandating, strategizing, mentoring, consulting, and operating. The recruiting activities comprise "advising, doing reference checks, recruiting, negotiation, assessment, and replacement;" mandating activities cover "providing contract and policy terms, control rights, stock rights, contingent rights, performance targets, reports, and controls;" strategizing activities encompass "developing business concept/strategies, doing strategic planning, and keeping focus on longer-term strategic direction;" mentoring activities consist of "providing mentorship, advice, coaching, guidance, facilitation, feedback, motivation, patience, moral support, friendship; acting as confidant, sounding board, and implanting entrepreneurial orientation;" consulting activities comprise "providing business intelligence, contacts, expertise, competence, and teach business skills;" and operating activities include "providing decision making, compensation and incentives, appraisals, discipline, day-to-day hands-on management, professionalization, and managing crises and problems."

Unlike the above activities that mainly seek to add value to the company, monitoring and control activities carried out by the venture capitalist are oriented to protect the value of the investment, and to reduce agency and business risks (Arthurs \& Busenitz, 2003). Monitoring activities include observing the operational, financial, business strategy, and product-market performance of the venture (Maunula, 2006). Monitoring cannot be carried out on a continuous basis and it is costly. This high cost of monitoring remote companies may partially explain the tendency of venture capitalists to invest in firms that are close to them (Bernstein, Giroud, \& Townsend, 2016). Monitoring the performance of the company helps spot variations according to plan, and controls allow correcting such variations (Kaplan \& Stromberg, 2002). Among the most powerful control mechanisms that venture capitalists have are staged financing and replacing the CEO. Staged financing gives the venture capitalist the option of abandoning his effort if he is not certain of the growth potential of the company (De Clercq, Fried, Lehtonen, \& Sapienza, 2006), and replacing the CEO, which in most cases means taking away the role of leader from the entrepreneur, is a measure taken by the venture capitalist when the entrepreneur cannot transition to a manager's role (Hellmann \& Puri, 2002). 


\section{Indirect Contributions}

In addition to the so-called direct contributions of the venture capitalist, there are indirect contributions made by the venture capitalist to the company through his business networks and reputation (Davila, Foster, \& Gupta, 2003). An important feature of a successful venture capitalist is his specialized business networks and his ability to leverage these business relationships for the benefit of the venture (Bottazzi \& Da Rin, 2002). Usually made up of entrepreneurs, lawyers, consultants and experts familiar with recently created firms, his business networks help the venture accomplish goals such as identifying management team's candidates, sourcing strategic information, creating alliances to drive the growth of the company, obtaining additional financing, and reducing information asymmetries in an initial public offering (Campbell \& Frye, 2006). His business networks are a scarce resource and have a limited reach, thus the tendency of the venture capitalist to invest in companies in a given geographical location (Gompers \& Lerner, 2006).

On the other hand, the reputation of the venture capitalist is related to his ability to generate value. A history of backing successful ventures significantly enhances the reputation of the venture capitalist (De Clercq et al., 2006). The immediate availability of success and failure stories on the Internet and the compact nature of entrepreneurs' and venture capitalists' communities ensure that reputation is improved or damaged without delay (Metrick \& Yasuda, 2011). A good reputation brings about benefits to the venture. Talented people are more likely to work in a company funded by a reputed venture capitalist because they perceive the venture has a higher probability to succeed (Davila et al., 2003). Moreover, a prestigious venture capitalist gets loans from banks with better terms (Hellmann, Lindsey, \& Puri, 2008), attracts high-quality capital investors and increases the probability to materialize returns for his investors (Kaplan \& Lerner, 2010), and obtains higher venture's valuation in an initial public (Bottazzi \& Da Rin, 2002). Venture capitalist's reputation also attracts investors. A venture capitalist that delivers results to their investors the first time, will likely continue to appeal to investors for his next endeavor (Metrick \& Yasuda, 2011).

\section{Debate Around Value-Added}

Although the activities of the venture capitalist have been formally studied, there is still debate about the venture capitalist's contributions to the venture. Research suggests that the venture capitalist contributes significantly to the success of the company through his active participation in growing the venture, and that the value perceived by the entrepreneur and the performance of the venture are highly correlated (Busenitz, Fiet, \& Moesel, 2004; Dimov \& Shepherd, 2005; Edelman, 2002). Moreover, entrepreneurs believe in the venture capitalists' ability to add value to the venture (Bengtsson \& Wang, 2010). Also, the value added by the venture capitalist to the venture impacts positively the results of the company. Companies financed with venture capital perform better that those similar companies without this kind of financing (Campbell \& Frye, 2006), and companies backed with venture capital are better valued in an initial public offering (Dolvin \& Pyles, 2006). In addition, venture capitalists' investments outperform the public equity market (McKenzie \& Janeway, 2011). Finally, contributions of the venture capitalist to the venture are related to innovative developments. An increase in venture capital in a given industry causes a significant increase in the rate of patent registrations in the industry (Kortum \& Lerner, 2000).

On the other hand, other research questions the value added by the venture capitalist, whether the firm receives any contribution from the venture capitalist, whether it receives sufficient value, or whether it receives the needed value. How the venture capitalist adds value to the venture remains a focus of debate without consensus in the answers (Bottazzi \& Da Rin, 2002), and despite the direct involvement of the venture capitalist in the development of the venture, his contributions are little understood (Wijbenga, Postma, Van Witteloostuijn, \& Zwart, 2003). In addition, venture capital backed companies perform no better than non-venture capital backed similar companies (C. K. Wang, Wang, \& Lu, 2003). Moreover, when viewed as a process, the non-financial contributions of the venture capitalist are far from being understood since there is no consensus on inputs and outputs nor on their relevance, making it very difficult to improve the efficiency of the venture capitalist's value contributions (Large \& Muegge, 2008). Finally, the performance of venture capital is also refuted. For example, the aggregate performance of the venture capital funds is not different from that of the stock market (Kaplan \& Schoar, 2005). From above, it becomes evident that there is an opportunity to improve the understanding of venture capitalist's non-monetary contributions to the venture. Thus, explaining how the venture capitalist adds value to the venture will help with this endeavor.

\section{Method}

The approach of the study was qualitative and relied on the grounded theory methodology. First, data were collected through interviews with venture capitalists and entrepreneurs from seven venture capital funds in Mexico City and two in Monterrey. The interviews were carried out by the author in person and individually with an interview guide with open questions that was pilot tested with industry's experts. The guide was structured to capture information on whether the venture capitalist added value to the venture, on the nature of the value-added, on the relevance of the value-added, and on the impact of the value-added on the venture's development. Interviews were conducted at the participants' work place to find about their work environment and to achieve high quality audio. During the interviews 1,414 minutes of audio were recorded, $48 \%$ of those minutes came from venture capitalists and $52 \%$ from entrepreneurs. The study was performed using the transcribed audio that resulted in 503 singlespaced Arial-12 pages. The data were then analyzed with qualitative lens using the grounded theory methodology, as proposed originally by Glaser \& Strauss (2006).

The grounded theory methodology is commonly used to study abstract and process-like problems in a given social context (Glaser, 1992). Given that venture capital financing is a complex phenomenon involving frequent interactions between the venture capitalist and the 
entrepreneur, and that the venture capital financing phenomenon is barely known in Mexico and rarely researched, more so from the qualitative perspective, grounded theory was the method of choice for analyzing data. From the beginning of the study, the development of a theory with explanatory power was sought. The "glaserian" version of grounded theory used in this study defends the method of discovery where variables and categories arise from data and where each category intertwines with others to bring about the emergence of a substantive theory (Charmaz, 2006). The substantive theory is a theory of intermediate rank that arises from the analysis of data in texts on a particular subject, and can be used as an input to construct formal theories. The study proposes to generate a substantive theory from analyzing empirical data from participants, both inductively and deductively.

The grounded theory methodology offers not only a philosophical direction for the development of a substantive theory but also proposes a method to assist the researcher in all aspects of data collection and analysis, and the writing of the theory (Glaser, 2002). The study used the constant comparison analysis method proposed originally by Glaser \& Strauss (2006). This process of analysis is comprised of four stages: (a) the codification and the comparison of incidents; (b) the integration of categories and the definition of its properties, (c) the delimitation of the theory, and, finally, (d) the writing of the theory. At first glance, the method of constant comparison analysis may seem a simple linear process, in practice, however, is a complex process since collection of data and their analysis occur simultaneously. The researcher must return to each of the previous stages as the study progresses, and each stage of the process is an integral part of the development of the grounded theory (Glaser, 1978).

In addition to the constant comparison analysis method, different analysis techniques were used at each stage to assist with the development of the theory. Techniques such as focused and theoretical coding, diagrams, and memos, as described by Charmaz (2006). Open coding was used to identify facts, characteristics, experiences, phrases and explanations that recurrently appeared in the participants' data, and were recorded as codes. By using conceptual codes, focused coding identified preliminary categories, helped name categories, and allowed to saturate or complete categories. Theoretical codification served to relate categories and integrate them into a theory. Following Glaser (1978)'s recommendation for the researcher who starts with data analysis based on grounded theory, the theoretical code used was the Six-Cs, namely, causes, consequences, contingencies, conditions, covariance, and context. This family code fits the model condition- cause-consequence of the present study. In addition, diagrams were used to integrate and to configure and relate categories, and to show the connections between them. Finally, memos, which are records of processes, thoughts, feelings, analytic perceptions, decisions, and ideas related to the study that arise from questions about concepts, were used throughout the study for the writing of the grounded theory. From data arise codes, from codes emerge categories, and from categories emanates the substantive theory. The memos are the basic element that serves to amalgamate these components in search of the grounded theory.

Special care was taken to ensure quality in this study by observing the criteria defined by Charmaz (2006) related to the use of grounded theory methodology for capturing and analyzing data. The participants were the top managers of their organizations; general partners and chief executive officers. Sufficient data was gathered from both parties, venture capitalists and entrepreneurs, to provide a full range of contexts of the study of value-added. Moreover, given that the constant comparison method demands to continuously reviewing the coding of the information, once the data was coded manually, the coding process was repeated several times using the HyperResearch, specialized qualitative research software from Researchware Inc., to re-code data and manage codes. Finally, the results of the study were commented by participants: the resulting categories made sense to practitioners, and provided new insights to the value-adding process.

\section{Results}

The nine interviewed dyads, that is, nine venture capitalists and nine entrepreneurs in their portfolios, amounted for $100 \%$ of the venture capital funds, $38 \%$ of venture capitalists investing in companies in the country, and $27 \%$ of the ventures funded with venture capital in 2014. Profiles of the participants and their organizations are shown in Table 1. On average, the venture capitalists are 41 years old individuals, with high level of education, and have two years of funding experience. The size of their funds is $\$ 20$ million dollars and have two invested ventures in their portfolios. On the other hand, the entrepreneurs are 42 years old individuals with mostly no previous experiences in launching ventures. Their ventures have four years in operation, three of those years with venture capital, employ 70 people, have annual sales of $\$ 3$ million dollars, and were funded with $\$ 2$ million dollars of venture capital. From a relationship perspective, two-thirds of venture capitalists are older than their related entrepreneurs, and more than three-quarters of venture capitalists have a higher level of education than their related entrepreneurs. 
Table 1. Profile of participants and their organizations

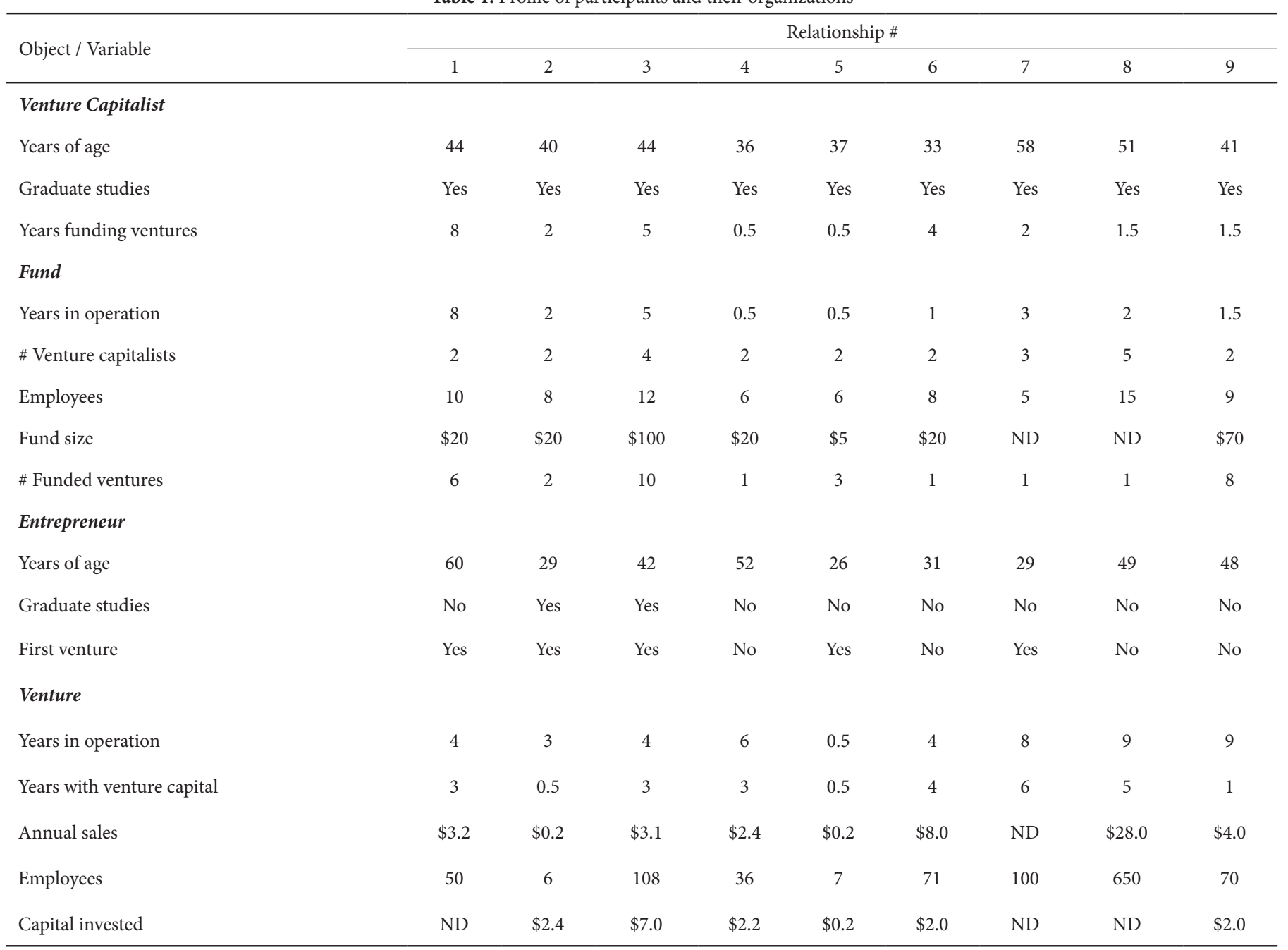

Source: Elaborated by author.

Note: Fund size, annual sales, and capital invested are in million dollars. ND means non-disclosed information.

\section{Codes and categories}

Data collected from participants resulted in codes, codes were integrated into categories, and the categories defined a substantive theory. 66 codes emerged from the data. Each of these codes contains words, phrases or concepts with similar meanings. Of these codes, 31 were common to venture capitalists and entrepreneurs, 11 were exclusi- ve to entrepreneurs, 17 were exclusive to venture capitalists, and seven additional selective coding codes from literature completed the categories. To help with the integration of the categories and their relationships, in this section codes are referred to with italics and categories with SMALL CAPS ITALICS. The codes and their sources are summarized in Table 2. The same table also shows the resulting categories that are addressed in the following paragraphs. 
Table 2. Codes and categories generated from participants' data

\begin{tabular}{|c|c|c|}
\hline Code & Source & Category \\
\hline ability to execute & VC, E & GROWTH \\
\hline active participation & VC, E & RELATIONSHIP \\
\hline advisor & $\mathrm{VC}, \mathrm{E}$ & INVOLVEMENT \\
\hline appreciation & $\mathrm{VC}, \mathrm{E}$ & EXIT \\
\hline being receptive & $\mathrm{VC}$ & RELATIONSHIP \\
\hline best practices & $\mathrm{VC}, \mathrm{E}$ & INVOLVEMENT \\
\hline board member & $\mathrm{VC}, \mathrm{E}$ & INVOLVEMENT \\
\hline business environment & $\mathrm{E}$ & INVOLVEMENT \\
\hline business relationships & VC, E & ENDORSEMENT \\
\hline CEO replacement & $\mathrm{L}$ & INVOLVEMENT \\
\hline certainty & VC E & ENDORSEMENT \\
\hline commitment & VC, E & GROWTH \\
\hline common goal & VC, E & EXIT \\
\hline common sense & $\mathrm{VC}$ & INVOLVEMENT \\
\hline consultant & $\mathrm{VC}, \mathrm{E}$ & INVOLVEMENT \\
\hline controls & $\mathrm{VC}, \mathrm{E}$ & INVOLVEMENT \\
\hline credibility & $\mathrm{E}$ & ENDORSEMENT \\
\hline discipline & $\mathrm{VC}$ & INVOLVEMENT \\
\hline endorsement & $\mathrm{E}$ & ENDORSEMENT \\
\hline execution & VC & GROWTH \\
\hline exit & $\mathrm{E}$ & EXIT \\
\hline experience & $\mathrm{E}$ & INVOLVEMENT \\
\hline fast growth & $\mathrm{L}$ & GROWTH \\
\hline financial return & $\mathrm{VC}, \mathrm{E}$ & EXIT \\
\hline financing & $\mathrm{VC}$ & INVOLVEMENT \\
\hline focus & VC, E & GROWTH \\
\hline goals' alignment & $\mathrm{VC}$ & EXIT \\
\hline incentives & VC, E & GROWTH \\
\hline institutionalization & VC, E & INVOLVEMENT \\
\hline investments & $\mathrm{VC}$ & ENDORSEMENT \\
\hline justice & $\mathrm{L}$ & RELATIONSHIP \\
\hline key employees & $\mathrm{E}$ & INVOLVEMENT \\
\hline knowledge & $\mathrm{E}$ & INVOLVEMENT \\
\hline leading company & VC & EXIT \\
\hline mentor & $\mathrm{L}$ & INVOLVEMENT \\
\hline milestones & $\mathrm{VC}$ & GROWTH \\
\hline money & $\mathrm{E}$ & INVOLVEMENT \\
\hline orderliness & $\mathrm{VC}, \mathrm{E}$ & INVOLVEMENT \\
\hline outsourcing & VC, E & INVOLVEMENT \\
\hline performance feedback & $\mathrm{VC}, \mathrm{E}$ & INVOLVEMENT \\
\hline performance goals & $\mathrm{VC}, \mathrm{E}$ & GROWTH \\
\hline performance measurement & VC, E & GROWTH \\
\hline professionalization & $\mathrm{L}$ & INVOLVEMENT \\
\hline promotion & $\mathrm{VC}, \mathrm{E}$ & INVOLVEMENT \\
\hline quality stamp & VC & ENDORSEMENT \\
\hline reason & VC & INVOLVEMENT \\
\hline relationship & $\mathrm{VC}, \mathrm{E}$ & RELATIONSHIP \\
\hline reporting & VC, $\mathrm{E}$ & GROWTH \\
\hline reputation & $\mathrm{VC}, \mathrm{E}$ & ENDORSEMENT \\
\hline respect & VC, E & RELATIONSHIP \\
\hline results & $\mathrm{VC}$ & GROWTH \\
\hline sale & $\mathrm{VC}$ & EXIT \\
\hline sense of urgency & $\mathrm{VC}$ & GROWTH \\
\hline shared vision & $\mathrm{VC}, \mathrm{E}$ & EXIT \\
\hline smart capital & VC, E & INVOLVEMENT \\
\hline sounding board & $\mathrm{E}$ & INVOLVEMENT \\
\hline staged investments & VC, E & INVOLVEMENT \\
\hline success stories & $\mathrm{E}$ & ENDORSEMENT \\
\hline suitability & $\mathrm{VC}$ & RELATIONSHIP \\
\hline support & $\mathrm{L}$ & ENDORSEMENT \\
\hline talent & $\mathrm{VC}$ & ENDORSEMENT \\
\hline think big & $\mathrm{VC}$ & GROWTH \\
\hline timely & $\mathrm{L}$ & EXIT \\
\hline transparency & $\mathrm{E}$ & RELATIONSHIP \\
\hline trust & $\mathrm{VC}, \mathrm{E}$ & RELATIONSHIP \\
\hline value & $\mathrm{VC}, \mathrm{E}$ & EXIT \\
\hline
\end{tabular}

Source: Elaborated by author.

Note: "VC" means data from venture capitalist, "E" data from entrepreneur, and "L" data from literature. 
Five categories were integrated from these 66 codes: ENDORSE$M E N T$ with 10 codes, EXIT with 10 codes, GROWTH with 13 codes, INVOLVEMENT with 25 codes, and RELATIONSHIP with eight codes. Table 2 shows the results of coding integration. The integrated categories are described in the following paragraphs.

ENDORSEMENT contains the codes: business relationships, certainty, credibility, endorsement, investments, quality stamp, reputation, success stories, support and talent. The category emphasizes that the company financed with venture capital benefits from the reputation and business relationships of the venture capitalist. The more investments the venture capitalist makes, the greater the reach and effectiveness of his business relationships and the greater the likelihood that the investments will result in success stories. More success stories increase the reputation of the venture capitalist, which translates into stronger endorsement and support for the venture. A stronger endorsement assigns greater certainty to the business, attracts talent to the venture, increases the credibility of the business opportunity, and overall prints a quality stamp to the company.

EXIT contains the codes: appreciation, common goal, exit, financial return, goals' alignment, leading company, sale, shared vision, timely, and value. The category accentuates the importance for the venture capitalist to timely complete their investment cycle with an exit. From the beginning of their relationship, the venture capitalist promotes a shared vision with the entrepreneur, seeks goals' alignment and makes sure that the exit of the investment becomes the common goal. To accomplish the exit, the venture capitalist captures the attention of potential buyers. He works with the entrepreneur to increase the value of the venture and to transform the venture into a leading company. At the end, the venture capitalist prepares the company for sale, communicates the company's appreciation to potential buyers, and sells the firm to get a financial return for his investment.

GROWTH is formed by the codes: ability to execute, commitment, execution, fast growth, focus, incentives, milestones, performance goals, performance measurement, reporting, results, sense of urgency, and think big. The category emphasizes that the entrepreneur is the one who operates the company and the one who is responsible for the execution of the business plan and the growth of the venture. The venture capitalist assists the entrepreneur so that the venture achieves fast growth. In particular, the venture capitalist motivates the entrepreneur to think big and to execute the development of the company with a sense of urgency. In addition, the venture capitalist designs incentives to focus entrepreneur's efforts, appeals to the entrepreneur's commitment to performance goals and milestones, and, in general, to getting results. On the other hand, based on his ability to execute, the entrepreneur gets results, carries out performance measurement of the venture's development, and does the reporting of the achieved results.

INVOLVEMENT contains the codes: advisor, best practices, board member, business environment, CEO replacement, common sense, consultant, controls, discipline, experience, financing, institutionalization, key employees, knowledge, mentor, money, orderliness, outsourcing, performance feedback, professionalization, promotion, reason, smart money, sounding board, and staged investments. The category calls attention to the active participation of the venture capitalist in the development of the venture, both informally and from the board of directors as a board member. The venture capitalist relies on his experience and knowledge, in particular about the business environment and best practices, to work hand in hand with the entrepreneur to grow the company. In doing so the venture capitalist privileges the use of reason and common sense. Also, the venture capitalist plays the triple role of advisor, consultant, and mentor for the entrepreneur, hence the venture capitalist's money is called smart money. Also, the venture capitalist drives the institutionalization of the venture by creating a sounding board, by introducing orderliness and discipline into venture's operation, by hiring key employees, by encouraging the professionalization of the activities, and by outsourcing non-core functions. Moreover, the venture capitalist gives performance feedback to the entrepreneur, and exerts particularly two kinds of controls to ensure the venture performs according to expectations, namely the CEO replacement and staged investments. Finally, the venture capitalist carries out the promotion of the venture, and helps the entrepreneur get additional financing.

Last, RELATIONSHIP is made of the codes: active participation, being receptive, justice, relationship, respect, suitability, transparency, and trust. The category underlines the importance of building and maintaining a good relationship between the venture capitalist and the entrepreneur throughout the investment cycle. The relationship starts when the venture capitalist confirms the entrepreneur's suitability, mainly by assessing his ability to execute and his capacity of being receptive of venture capitalist's advice to improve his own and venture's performance. Trust, respect and results are conducive to a good relationship. Trust is the result of the transparency in the venture capitalist - entrepreneur's interactions, and the justice perceived by the parties when making decisions. More transparency and better perception of justice result in a better relationship. Also, results achieved by the entrepreneur affect the relationship. The relationship deteriorates if the company does not get the planned results. Finally, a good relationship is related to an active participation of the venture capitalist. The above five categories are related to each other, and define the substantive theory described below.

\section{The Substantive Theory}

The present study argues that the contributions of the venture capitalist are intended to build an exit for his investment. EXIT is the central category and the basic social process that resulted in a substantive theory. The category EXIT explains the main issues about the value contributions of the venture capitalist to the development of the venture, and points out the final goal of the venture capitalist's value-adding process that is to provoke an exit. The following examples from participants and the literature highlight the importance of the EXIT:

"The venture capitalist has a clear and evident intention of high profitability because it represents also the commitment he made to his investors. The venture capitalist has to be very profitable for his investors, so the first thing he wants is that the exit is a convenient outcome for his investors." (Entrepreneur \# 1) 
"The venture capitalist cares about his exit model, that was very clear to me from the beginning of the negotiations. He had a strong position on that. He wanted a safe way out for his investment." (Entrepreneur \# 9)

"VCs' nature is that they need an exit point. This is how they make their money - only on the exits. Therefore, it is not good to them to have a management team that wants to build a perfect company over 20 years. ... VCs want out as fast as they can. The minute they buy your share, their only concern is whom they are going to sell their shares to. Short-term profit is not a priority item. It does not matter at all. These are the dippiest, darkest secrets of the VC world." (Țurcan, 2008)

EXIT is also a basic social process as it is evident in the following observation from one of the participants:

\begin{abstract}
"The entrepreneur must prove that with the money, he will be able to develop the venture and achieve goals: he needs to make the venture generate positive cash flows; he needs to turn the company into a relevant player in its niche; and he needs to make the company an attractive target for a strategic buyer, or for some other market player, to cause a way out for the investment." (Venture Capitalist \# 1)
\end{abstract}

This basic social process resulted in the substantive theory BUILDING AN EXIT FOR THE INVESTMENT. SMALL CAPS are used here to refer to the substantive theory. This mid-range theory explains a phenomenon in a specific area, how the venture capitalist adds value to the venture, and could possibly contribute to the development of a general theory of universal scope. The theory that arises from the very essence of the data is reported in a simple relational structure shown in Figure 1. The theory has explanation, scope, and relevance for the venture capitalist's value contributions to the venture.

Figure 1. Structure of the Substantive Theory BUILDING AN EXIT FOR THE INVESTMENT

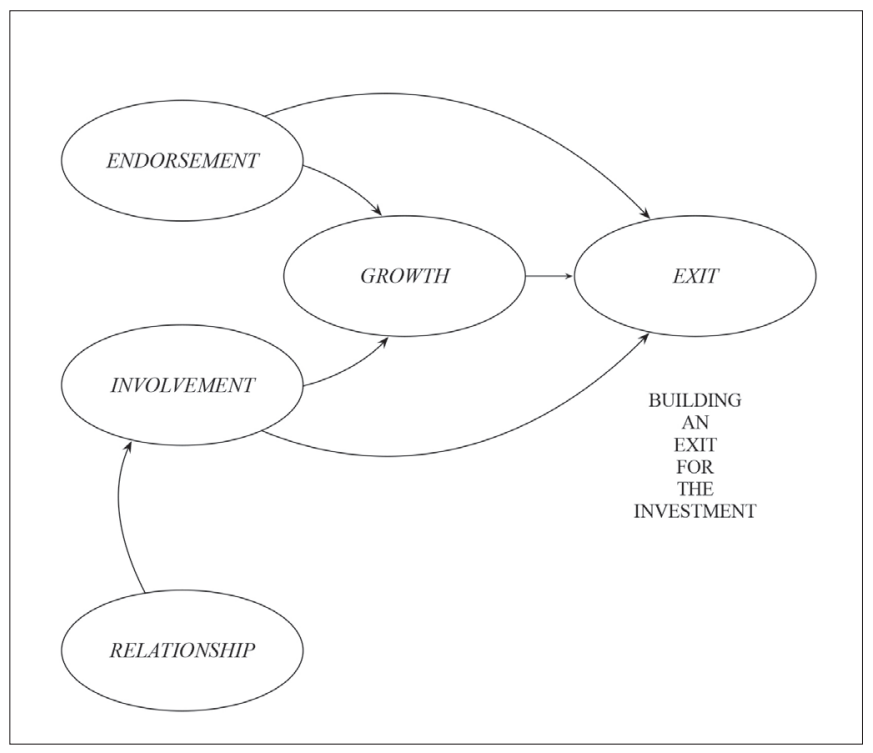

The five categories emerging from the data of the participants are intertwined to BUILDING AN EXIT FOR THE INVESTMENT. The ENDORSEMENT effect of the venture capitalist contributes to the GROWTH of the venture and enables an EXIT event. The reputation of the venture capitalist and his business relationships open doors to the venture and allow the entrepreneur to have access to resources otherwise unavailable such as the talent needed to potentiate GROWTH. The stronger the ENDORSEMENT is, the higher the prospects to grow. ENDORSEMENT also affects the EXIT of the investment. The venture capitalist's experience in selling companies helps to effectively carry out activities conducive to the EXIT of the investment, such as identifying new investors, and defining and negotiating the terms of the EXIT, thus increasing the likelihood of an EXIT. On the other hand, an EXIT that results in a success story improves the ENDORSEMENT effect of the venture capitalist. Venture capitalist's INVOLVEMENT influences GROWTH and EXIT. Although the entrepreneur is responsible for executing the GROWTH of the company, the venture capitalist's INVOLVE$M E N T$ conduces the entrepreneur towards accelerated GROWTH. The more INVOLVEMENT is, the higher the GROWTH of the venture. In addition, the venture capitalist's knowledge and experiences in EXIT events increase the probability of an EXIT. The more INVOLVEMENT of the venture capitalist increases EXIT options and improves the chances of obtaining a better yield.

GROWTH of the venture depends on the ENDORSEMENT effect of the venture capitalist and on the venture capitalist's $I N$ VOLVEMENT in the venture. GROWTH, in turn, is a condition of the EXIT of the investment. Over time, the focused and orderly GROWTH increases the value of the venture, attracts potential buyers, and increases the probability of an EXIT. The RELATIONS$H I P$ venture capitalist - entrepreneur is impacted by the GROWTH of the company. A venture's high GROWTH leads to a better RELATIONSHIP that in turn fosters the venture capitalist's INVOLVEMENT. On the contrary, a bad RELATIONSHIP caused by bad results could translate into the dismissal of the entrepreneur as the CEO of the company. Finally, EXIT is the result of the venture capitalist's ENDORSEMENT effect and his direct INVOLVEMENT in the company, and of the GROWTH of the venture. An EXIT event has an effect on the venture capitalist's continuing operations. A known EXIT that represents a success story attracts new investors and allows the venture capitalist to create a new fund. Also, success stories from a given venture capitalist attract more entrepreneurs looking forward to being invested by such venture capitalist.

\section{Value-added in Mexico}

The venture capitalist in Mexico not only provides equity to the venture but also contributes with non-financial resources to the company, and, like Hsu (2004), concludes that in Mexico the source of capital is as important as the capital itself. From the participants' perspectives, both venture capitalists' and entrepreneurs' perceive that the venture capitalist adds value to the company. To develop the venture, the venture capitalist in Mexico carries out activities similar to those accomplished by his American counterparts. These activities are described at 
length in Large \& Muegge (2008). However, the study highlights three activities particular to the venture capitalist in Mexico: the outsourcing of venture's non-core functions to the venture capitalist's fund, the focused search for an acquisition exit, and the initial conversion of the venture to a specialized kind of business unit.

The venture capitalist structures his own fund's internal functions, such as accounting, legal, information technology, and human resources, to provides shared services to his portfolio's ventures for a fee. As a result, at least during the early venture's development stages, the venture lacks these functions, and it is not clear when and how the venture recoups these functions to perform as a standalone company. The second difference is that the venture capitalist directs all his efforts to accomplish a trade sale of the venture and not an initial public offering, IPO like his American counterparts. This condition is apparently imposed over the Mexican venture capitalist due to current regulation and the small size of the stock market in Mexico that make very difficult to list a venture capital-backed company. Finally, in his effort to institutionalize the venture, one of the first tasks of the venture capitalist in Mexico is to ensure that the venture business unit is converted into a Sociedad Anónima Promotora de Inversión, S.A.P.I. The venture capitalist can invest his money only in businesses with S.A.P.I. denomination. Considering that this is a new type of business unit in Mexico and that most of the time entrepreneurs are not aware of it and they create their ventures with traditional denominations, the venture capitalist needs to help the entrepreneur to make the venture's conversion in his effort to institutionalize the firm.

\section{Conclusions}

The substantive theory that emerged from participants' data argues how the venture capitalist adds value to the venture for building an exit for his investment. To accomplish an exit, the venture capitalist makes use of his experience and knowledge to directly add value to the venture, and of his reputation and business relationships to add value through third parties. The venture capitalist works hand in hand with the entrepreneur to grow the company, make it profitable, sell it, and make a return on the investment. The study also revealed the importance of the relationship between the active investor and the responsible for executing the venture's growth plan to achieve this goal. A good venture capitalist - entrepreneur relationship is essential for the sustained development of the venture and to accomplish the goal of exiting the investment.

This exit goal, however, contrasts with existing views in the literature that relate venture capitalist's value-added with achieving company's milestones (De Clercq et al., 2006), with improving venture performance (Busenitz et al., 2004), with growing the company (Croce, Martí, \& Murtinu, 2012), with increasing the financial value of the venture (De Clercq et al., 2006), and with achieving a target company's size in a given time span (Maunula, 2006). Although these goals are somehow related, for example, achieving milestones improve the performance of the company, better company's performance translates into venture growth, growth improves the venture's financial value and is required to achieve a desired venture size, and higher financial value for the venture improves the probability of achieving an exit for the investment, the exit of the investment is necessary to make a return on the venture capitalist's investment. As a result, the ultimate goal of venture capitalist's value-added is to exit his investment.

On the other hand, this particular finding of the venture capitalist's exit goal suggests that attempts to measure venture capitalist's valueadded should be related to the exit of the investment. The above supports Large \& Muegge (2008) who argue "that future studies should examine 'VC exit success' as a high-impact dependent variable, and place greater emphasis on the measurement of directly observable events for both value-adding inputs and value-added outcomes". The exit becomes a condition to measuring value-added, that is, there is value-added when an exit is accomplished. To measure the value-added by the venture capitalist, one should consider the type of exit and relate it to the expected venture capitalist's contributions. Cumming, Fleming, \& Suchard (2005) find that "there are five primary types of venture capital fund exits: initial public offerings (IPOs, or new listings on a stock exchange for sale to the general public), acquisitions (in which the venture capital fund and entrepreneur sell to a larger firm), secondary sales (in which the venture capital fund sells to another firm or another investor, but the entrepreneur does not sell), buybacks (in which the entrepreneur repurchases the interest of the venture capital fund), and write-offs (liquidations)." Once the relationships type of exit - expected venture capitalist's valueadded are known, one could measure and improve value-added.

Given the importance of building an exit for the investment, the highgrowth entrepreneur should choose a venture capitalist with good reputation and effective business networks to help the venture grow, and with proven success stories about how the venture capitalist multiplied several times his initial investment by achieving an exit. In addition, the entrepreneur not only has to come up with an innovative venture to qualify for venture capital financing, but he also needs to know how to grow a company, manage people, and get results. When the entrepreneur lacks these abilities, the entrepreneur should choose a venture capitalist with proven success in accompanying venture's investments. In any case, entrepreneurs need to be aware and be prepared to work together with the venture capitalist to develop the venture, to be receptive to recommendations from the venture capitalist on how to improve personal and venture performance, and to act accordingly.

Finally, given the larger size of the venture capital industry in Mexico, future research on the value added by the venture capitalist to the venture should move beyond anecdotal stage and dependence on individual testimonies to a general study. This study identified already the significant variables and their relationships of the value-adding process, thus further research should be directed to answer the central question how to measure venture capitalist's value-added. An extension to this study should be related to understanding the relationship between the properties and characteristics of the exits achieved by venture capitalists in Mexico and the value-added to the venture. A growing number of companies with disruptive business models, aggressive government support to the industry, and a growing number of venture capital funds in the country, are big motivations for continuing doing research on venture capital. 


\section{References}

Arthurs, J. D., \& Busenitz, L. W. (2003). The boundaries and limitations of agency theory and stewardship theory in the venture capitalist - entrepreneur relationship. Entrepreneurship: Theory and Practice, 28(2), 145-162.

Baum, J. A. C., \& Silverman, B. S. (2004). Picking winners or building them? Alliance, intellectual, and human capital as selection criteria in venture financing and performance of biotechnology startups. Journal of Business Venturing, 19(3), 411-436.

Bengtsson, O., \& Wang, F. (2010). What matters in venture capital? Evidence from entrepreneurs' stated preferences. Financial Management, 39(4), 1367-1401.

Bernstein, S., Giroud, X., \& Townsend, R. R. (2016). The impact of venture capital monitoring. The Journal of Finance, 71(4), 1591-1622.

Bottazzi, L., \& Da Rin, M. (2002). Venture capital in Europe and the financing of innovative companies. Economic Policy, 17(34), 229-270.

Busenitz, L. W., Fiet, J. O., \& Moesel, D. D. (2004). Reconsidering the venture capitalists' 'value added' proposition: An interorganizational learning perspective. Journal of Business Venturing, 19(6), 787-807.

Campbell, T. L., \& Frye, M. B. (2006). Venture capitalist involvement and the long-run performance of IPOs. The Journal of Private Equity, 10(1), 7-17.

Charmaz, K. (2006). Constructing grounded theory. Thousand Oaks, CA: SAGE Publications.

Croce, A., Martí, J., \& Murtinu, S. (2012). The impact of venture capital on the productivity growth of European entrepreneurial firms: 'Screening' or 'value added' effect? Journal of Business Venturing, 28(4), 1-22.

Cumming, D., Fleming, G., \& Suchard, J. (2005). Venture capitalist value-added activities, fundraising and drawdowns. Journal of Banking \& Finance, 29(2), 295-331.

Davila, A., Foster, G., \& Gupta, M. (2003). Venture capital financing and the growth of startup firms. Journal of Business Venturing, 18(6), 689-708.

De Clercq, D., \& Manigart, S. (2007). The venture capital post-investment phase: opening the black box of involvement. In H. Landström (Ed.), Handbook of research on venture capital (pp. 193-218). Northampton, MA: Eduard Elgar.

De Clercq, D., Fried, V. H., Lehtonen, O., \& Sapienza, H. J. (2006). An Entrepreneur's Guide to the Venture Capital Galaxy. The Academy of Management Perspectives, 20(3), 90-112.

Dimov, D. P., \& Shepherd, D. A. (2005). Human capital theory and venture capital firms: exploring "home runs" and 'strike outs'. Journal of Business Venturing, 20(1), 1-21.
Dolvin, S., \& Pyles, M. (2006). Venture capitalist quality and IPO certification. Venture Capital, 8(4), 353-371.

Edelman, L. F. (2002). German Venture-Capital Firms and PortfolioCompany Performance: What Types of Management Support Make a Difference? The Academy of Management Executive, 16(1), 156-157.

Estadísticas. (2017). Retrieved from https://amexcap.com/contenido/ estadisticas/

Gabrielsson, J., \& Huse, M. (2002). The venture capitalist and the board of directors in SMEs: roles and processes. Venture Capital, 4(2), 125-146.

Gage, D. (2012, September 20). The venture capital secret: 3 out of 4 start-ups fail. The Wall Street Journal.

Glaser, B. G. (1978). Theoretical sensitivity: Advances in the methodology of grounded theory. Mill Valley, CA: Sociology Press.

Glaser, B. G. (1992). Basics of grounded theory analysis: emergence vs forcing. Mill Valley, CA: Sociology Press.

Glaser, B. G. (2002). Conceptualization: On theory and theorizing using grounded theory. International Journal of Qualitative Methods, 1(2), 23-38.

Glaser, B. G., \& Strauss, A. L. (2006). The Discovery of Grounded Theory. New Brunswick, NJ: Aldine Transaction.

Gompers, P. A., \& Lerner, J. (2006). The venture capital cycle. Cambridge, MA: The MIT Press.

Hellmann, T., \& Puri, M. (2000). The interaction between product market and financing strategy: The role of venture capital. The Review of Financial Studies, 13(4), 959-984.

Hellmann, T., \& Puri, M. (2002). Venture capital and the professionalization of start-up firms: Empirical evidence. The Journal of Finance, 57(1), 169-197.

Hellmann, T., Lindsey, L., \& Puri, M. (2008). Building relationships early: Banks in venture capital. The Review of Financial Studies, 21(2), 513-541.

Hsu, D. H. (2004). What do entrepreneurs pay for venture capital affiliation? The Journal of Finance, 59(4), 1805-1844.

Kaplan, S. N., \& Lerner, J. (2010). It ain't broke: The past, present, and future of venture capital. Journal of Applied Corporate Finance, 22(2), 36-47.

Kaplan, S. N., \& Schoar, A. (2005). Private equity performance: Returns, persistence, and capital flows. The Journal of Finance, 60(4), 1791-1823.

Kaplan, S. N., \& Stromberg, P. (2002). Characteristics, contracts, and actions: Evidence from venture capital analyses. The Journal of Finance, 59 (5), 2177-2210. 
Knockaert, M., Lockett, A., Clarysse, B., \& Wright, M. (2006). Do human capital and fund characteristics drive follow-up behaviour of early stage high-tech VCs? International Journal of Technology Management, 34(1-2), 7-27.

Kortum, S., \& Lerner, J. (2000). Assessing the contribution of venture capital to innovation. The RAND Journal of Economics, 31(4), 674-692.

Large, D., \& Muegge, S. (2008). Venture capitalists' non-financial value-added: An evaluation of the evidence and implications for research. Venture Capital, 10(1), 21-53.

Leece, D., Berry, T., Miao, J., \& Sweeting, R. (2012). The post-investment relationship between a venture capitalist and its investee companies. International Journal of Entrepreneurial Behavior \& Research, 18(5), 587-602.

Lerner, J. (2009). Boulevard of broken dreams. Princeton, NJ: Princeton University Press.

Maunula, M. (2006). The perceived value-added of venture capital investors: Evidence from Finnish biotechnology industry (pp. 1-94). Discussion paper. Retrieved from http://hdl.handle.net/10419/63655

McKenzie, M., \& Janeway, B. (2011). Venture capital fund performance. The Journal of Alternative Investments, 14(2), 24-35.

Metrick, A., \& Yasuda, A. (2011). Venture capital and the finance of innovation (Second). Hoboken, NJ: John Wiley and Sons.
NVCA. (2017). NVCA yearbook. Retrieved from nvca.org.

Overview of the venture capital industry in Mexico - October 2016. (2017). Retrieved from https://amexcap.com/contenido/overview-ofthe-venture-capital-industry-in-mexico-october-2016.

Ramírez, J. R. (2015). Estudio sobre la industria de capital emprendedor en México. Mexico City, DF: Ernst \& Young.

Sapienza, H. J., \& Gupta, A. K. (1994). Impact of agency risks and task uncertainty on venture capitalist-CEO interaction. Academy of Management Journal, 37(6), 1618-1632.

Sapienza, H. J., \& Villanueva, J. (2007). Conceptual and theoretical reflections on venture capital research. In H. Landström (Ed.), Handbook of research on venture capital (pp. 66-85). Northampton, MA.

Țurcan, R. V. (2008). Entrepreneur-venture capitalist relationships: Mitigating post-investment dyadic tensions. Venture Capital, 10(3), 281-304.

Wang, C. K., Wang, K., \& Lu, Q. (2003). Effects of venture capitalists' participation in listed companies. Journal of Banking \& Finance, 27(10), 2015-2034.

Wijbenga, F., Postma, T., Van Witteloostuijn, A., \& Zwart, P. (2003). Strategy and performance of new ventures: A contingency model of the role and influence of the venture capitalist. Venture Capital, 5(3), 231-250. 
